\title{
Intoxicação experimental por Dodonea viscosa (sapindaceae) em bovinos*
}

\author{
CRISTHIANE STECANELLA DE OLIVEIRA CATTANI
}

David Driemeier (Orientador - UFRGS)

Banca: Aldo Gava (UDESC), Cláudio Severo Lombardo de Barros (UFSM), André Silva Caríssimi (UFRGS)

Para verificar a toxidez e o quadro clínico e patológico da intoxicação por Dodonea viscosa em bovinos, a planta foi administrada para cinco bovinos onde quatro receberam folhas verdes e um recebeu folhas secas. Quatro dos bovinos que receberam as folhas verdes e secas apresentaram sinais clínicos e morreram. Um bovino não adoeceu e nem morreu. A planta mostrou-se tóxica a partir de $25 \mathrm{~g} / \mathrm{kg}$ de peso vivo. As folhas secas fornecidas na dose de $30 \mathrm{~g} / \mathrm{kg}$ mantiveram a toxidez. O menor período de evolução clínica nos que morreram foi de 3 horas e o maior foi de 19 horas.A evolução clínica foi cerca de 8,5h até a morte. O início dos sinais clínicos variou de 13 horas e 30 minutos a 45 horas. Os animais manifestaram apatia, anorexia, leve tenesmo, dificuldade para se manter em estação apoiando-se contra obstáculos, tremores musculares, decúbito esternal, movimentos de pedalagem, coma e morte. A alteração macroscópica mais significativa foi observada no fígado, que apresentava padrão lobular acentuado caracterizada por alternação de áreas vermelho-escuras, com o centro mais deprimido, intercaladas com áreas amarelo-claras conferindo ao órgão o aspecto de noz-moscada. Hemorragias petequiais foram encontradas em serosas de órgãos da cavidade abdominal e torácica e no intestino. A principal alteração microscópica foi observada no fígado que apresentou necrose coagulativa centrolobular ou massiva, associada à congestão e hemorragia.

Descritores: Dodonea viscosa, patologia de bovinos, Sapindaceae, planta hepatotóxica, necrose hepatocelular.

\footnotetext{
* Dissertação de Mestrado n. 364 (Especialidade: Patologia Animal). 37f. Programa de Pós-graduação em Ciências Veterinárias da Faculdade de Veterinária - UFRGS. CORRESPONDÊNCIA: C.S.O. Cattani [criscattani@zipmailcom.br].
} 


\title{
Experimental poisoning by Dodonea viscosa (sapindaceae) in cattle**
}

\author{
CRISTHIANE STECANELLA DE OLIVEIRA CATTANI
}

David Driemeier (Adviser - UFRGS)

Committee: Aldo Gava (UDESC), Cláudio Severo Lombardo de Barros (UFSM), André Silva Caríssimi (UFRGS)

Five bovines were fed with Dodonea viscosa leaves of the which, four were fed with green leaves and one with dried leaves. Clinical signs were observed in four bovines that died, one of the bovines did not present any clinical signs. The plant was proved toxic at dosages of $25 \mathrm{~g}$ per $\mathrm{kg}$ or higher. Dried leaves fed in the dose of $30 \mathrm{~g}$ per body weight remained toxic. All the animals that died presented clinical signs from 13 hours and 30 minutes to 45 hours after the ingestion of the plant and died around 48 hours. The clinical course from apperance of clinical signs to dead was about 8 hours and 30 minutes. The main clinical signs were apathy, anorexia, tenesmus, temporary unconsciosness, leaning the head against obstacles, muscle trembling, paddling movements, coma and dead.The most significant macroscopic lesion was observed in the liver, with accentuation on the lobular pattern, with alternad dark-red and light-yellow areas. Petechial were found in serosal membranes of the abdominal and thoracic organs. The main microscopic change observed was the hepatic centrolobular coagulative necrosis, associated with congestion and hemorrhagia.

Key words: Dodonea viscosa, Sapindaceae, bovine pathology, hepatotoxic plants, hepatocelullar necrosis.

\footnotetext{
** Master's Thesis no. 364 (Field: Veterinary Pathology). 37 p. Graduate Program in Veterinary Sciences, Faculdade de Veterinária - UFRGS. CORRESPONDENCE: C.S.O. Cattani [criscattani@zipmailcom.br].
} 